\title{
Towards a standardized and optimized protocol for rapid biodiversity assessments: spider species richness and assemblage composition in two savanna vegetation types
}

\author{
M.I. Muelelwa', S.H. Foord ${ }^{*}$, A.S. Dippenaar-Schoeman² \& E.M. Stam ${ }^{3}$ \\ ${ }^{1}$ Centre for Invasion Biology and Department of Zoology, University of Venda, Thohoyandou, O950 South Africa \\ ${ }^{2}$ ARC-Plant Protection Research Institute, Private Bag X134, Queenswood, 0121 South Africa, and \\ Department of Zoology and Entomology, University of Pretoria, Pretoria, 0001 \\ ${ }^{3}$ National Zoological Gardens of South Africa, P.O. Box 754, Pretoria, 0001 South Africa, and \\ Mammal Research Institute, University of Pretoria, Pretoria, 0001 \\ Received 5 November 2009. Accepted 8 June 2010
}

\begin{abstract}
A semi-quantitative inventory of spider diversity was done in the Blouberg Nature Reserve (BNR) and Western Soutpansberg Conservancy (WSC) situated in the Savanna Biome of the Limpopo Province, South Africa. Two hundred and ninety-six samples of one person-hour work each, comprised of five methods (vegetation beating, sweep netting, aerial hand collecting, ground hand collecting and leaf litter sifting) were divided between four relatively homogenous sites (plant communities) within a vegetation type of the BNR and WSC, respectively, an average of 37 per site. In addition, 25 pitfall traps were left open for a total of 20 days in each of the eight plant communities, 200 in total. We collected 1328 adult spiders representing 186 species of which $31 \%$ were singletons in the BNR vegetation type and 909 spiders in 222 species of which $41 \%$ were singletons in the WSC vegetation type. The number of species present was estimated using six estimators. The estimates varied between 233 and 307 for the BNR and 302 and 386 for the WSC. Inventory completeness was more than $70 \%$. However, the fit to a lognormal distribution suggests that there are 370 species (750 000 individuals) and 445 (850 000 individuals) species in the universes ( $16 \mathrm{ha}$ ) sampled within the two vegetation types. Collector experience had no effect on the results of the inventory, whereas time of day had a very small yet significant effect. Seasonality only affected abundance and richness, but not assemblage composition. Sampling methods used had the biggest effect on our results. These results are used to design an optimized sampling protocol for standardized inventories in the Savanna Biome.
\end{abstract}

Key words: inventory completeness, SANSA, species richness estimates, checklist, Araneae, Arachnida, Savanna Biome.

\section{INTRODUCTION}

Species richness and relative abundance of species in communities provide the basis for decisionmaking in conservation planning (Magurran 2004). Invertebrates are often neglected in conservation planning because of a lack of taxonomic and distributional data. Cardoso (2009) identified two factors that prevent the inclusion of invertebrates in conservation programmes, namely (1) comparability of results through standardization and (2) efficiency through optimized inventories. Coddington et al. (1991) proposed a sampling protocol for the rapid assessment of invertebrate diversity that can be structured to provide relative abundances of species at sites and enables

\footnotetext{
*Author for correspondence. E-mail: stefan.foord@univen.ac.za
}

comparisons between assemblages in disparate regions (Toti et al. 2000). This is a protocol where a sample is defined by one-person hour worth of effort in sampling spiders, employing an array of methods chosen to target different compartments of assemblages. A number of studies have adapted and applied this protocol for the temperate (Coddington et al. 1996; Scharff et al. 2003), tropical (Sørensen et al. 2002; Coscaron et al. 2009) and Mediterranean (Cardoso et al. 2008a,b; 2009) regions of the world.

Recent surveys of the spider fauna in the Western Soutpansberg have highlighted the contribution that this faunal component makes toward the diversity and uniqueness of this region with several new and endemic taxa described (Lotz 


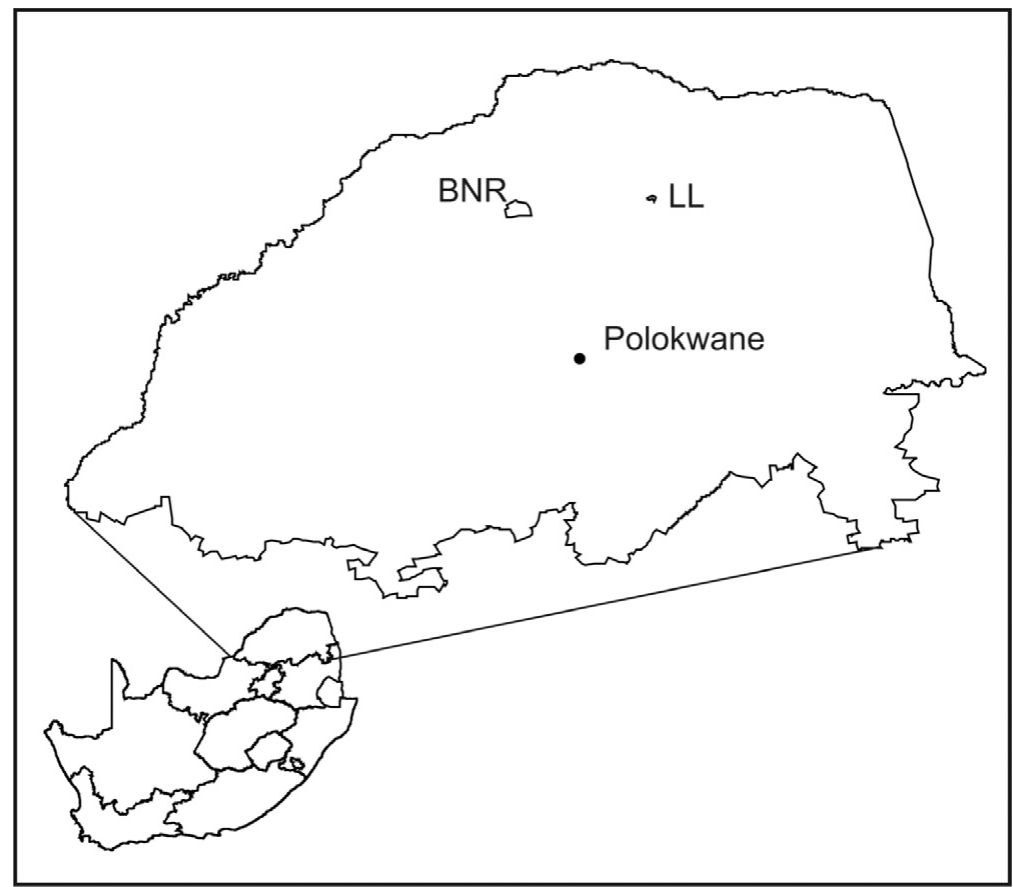

Fig. 1. Location of the Blouberg Nature Reserve (BNR) and the farm Little Leigh (LL) in the Western Soutpansberg Conservancy, Limpopo Province, South Africa.

2002; Huber 2003; Jocqué 2008; Haddad 2009). These studies were largely localized on the southern slopes, and upper elevations (1200- $1450 \mathrm{~m}$ a.s.l.) in the Western Soutpansberg (Foord et al. 2002, 2008). The South African National Survey of Arachnida (SANSA) enabled the broadening of this spatial scale to a more regional perspective of arachnid diversity. This paper summarizes the first of these studies focusing on two vegetation types in the northern parts of the Western Soutpansberg Conservancy (WSC) on the farm Little Leigh (LL) and Blouberg Nature Reserve (BNR). Both these areas form part of the recently announced Vhembe Biosphere Reserve (www.unesco.org).

As a first attempt, we designed a survey based on the Coddington protocol (Coddington et al. 1991) to: (1) generate a semi-quantitative database for the WSC and BNR, (2) determine sampling completeness and estimate species richness in these two areas, (3) evaluate the effect of season, time of day, and collecting methods on the abundance, species richness and community composition of adult spiders caught, and (4) explore the implications of these results for an optimized and standardized sampling protocol for spider inventories in the Savanna Biome.

\section{METHODS}

\section{Study area}

We identified two vegetation types in the Limpopo Province of South Africa for intensive sampling. They are $80 \mathrm{~km}$ apart and on the northern arid aspects of the Blouberg and Soutpansberg mountains respectively (Fig. 1). Mostert et al. (2008) described three vegetation types in the BNR that included the Eragrostis lehmanniana var. lehmanniana, Sclerocarya birrea subsp. caffra BNR Northern Plains Bushveld on the northern foothills of the Blouberg. This vegetation type formed the focus of the survey in the BNR. The second vegetation type was on the farm Little Leigh (Fig. 1), which falls within the Soutpansberg Leached Sandveld found in the WSC (Mostert et al. 2008). This Diplorhynchus condylocarpon/Burkea africana vegetation type is confined to the warmer northern slopes of the mountain, as well as some of the more arid southern slopes along the northernmost ridges of the mountain range (Mostert et al. 2008).

Four relatively homogenous plant communities (hereafter referred to as 'sites') were selected within each of the two vegetation types. The topography in the BNR was flat for all the sites and 
Table 1. Summary of sample replicates taken in each of the plant communities excluding pitfall trapping. BA = Burkea africana, GF = Gallery forest, $\mathrm{KA}=$ Kirkia acuminata, $\mathrm{KW}=$ Kirkia wilmsii, $\mathrm{PR}=$ Pterocarpus rotundifolius, $\mathrm{PV}=$ Philenoptera violaceae, $\mathrm{SB}=$ Sclerocarya birrea, $\mathrm{SA}=$ Spirostachys africana $\mathrm{A}=$ aerial collecting, $\mathrm{BB}=\mathrm{branch}$ beating, $\mathrm{G}$ = ground collecting, $\mathrm{LS}=$ leaf litter sifting; $\mathrm{SN}=$ sweep netting.

\begin{tabular}{lrrrrrrrrr}
\hline & BA & GF & KA & KW & PV & PR & SB & SA & Grand total \\
\hline A & 8 & 8 & 7 & 8 & 8 & 8 & 8 & 8 & 65 \\
G & 9 & 9 & 7 & 8 & 9 & 8 & 8 & 8 & 66 \\
BB & 8 & 9 & 9 & 8 & 9 & 8 & 8 & 8 & 67 \\
LS & 9 & 8 & - & - & 7 & 7 & 7 & 7 & 45 \\
SN & 8 & - & 7 & 7 & 8 & 9 & 7 & 7 & 53 \\
Grand total & 42 & 34 & 30 & 31 & 41 & 40 & 38 & 39 & 296 \\
\hline
\end{tabular}

consisted of, (1) a S. birrea open woodland, (2) a Kirkia acuminata mixed bushveld, (3) a Spirostachys africana open to semi-closed woodland and (4) a Philenoptera violaceae woodland. These sites were 864-904 $\mathrm{m}$ a.s.l. The sites in the WSC, based on the dominant tree species within each, were: (1) a riparian gallery forest, (2) the generally flat Burkea africana and Ochna pulchra mixed woodlands, (3) a steep, south-facing Kirkia wilmsii bushland with rocky soils, and (4) a flat Pterocarpus rotundifolius bushland. These sites were between 1084 and $1128 \mathrm{~m}$ a.s.l.

\section{Spider sampling}

Four spatial replicates were set out at each site, at least one $\mathrm{km}$ apart. All four replicates were surveyed on the same day between 07:00 and 17:00 by an eight-person survey team comprised of four undergraduate biology students and four academic staff members, including one experienced arachnologist. Owing to logistical constraints in the BNR, no night sampling was done at any of the sites. Each replicate consisted of an area $c .1$ ha in extent. Spider sampling within a replicate followed a protocol as set forth by Coddington et al. (1991). The sampling methods included vegetation beating (BB), litter sifting (LS), sweep netting (SN), ground hand collecting $(\mathrm{G})$, aerial hand collecting (A) and pitfall trapping (P). Except for pitfall trapping, each sample consisted of one hour of active sampling, measured with a stopwatch. Activities not related to sampling, such as fixing equipment or personal duties, were excluded from the sampling time (Coddington et al. 1991). Sampling methods were rotated between collectors during the course of a day, i.e. no one collector used the same method more than once at the same site. The different sampling techniques were chosen to target different spider species as each species has different habitat preferences (Foelix 1996). The effect of seasonal variability was captured by repeating this protocol in early (November/December 2005) and late summer (March 2006). An attempt was made to allocate equal sampling effort to all of the plant communities over the period of the survey (Table 1).

The vegetation beating comprised knocking spiders down from shrubs, high herb vegetation, bushes, small trees and branches with a heavy stick onto a white beating sheet $(50 \times 50 \mathrm{~cm})$ where spiders could easily be seen and captured with an aspirator. Leaf litter was transferred to a sieve $(50 \times 30 \times 20 \mathrm{~cm}$ and $5 \times 5 \mathrm{~mm}$ mesh) that was shaken over a white cloth after which the spiders were collected with an aspirator. Sweep net sampling, with a net $40 \mathrm{~cm}$ in diameter, was performed to extract spiders from vegetation that was too low or too soft for beating, such as grasses, herbs and short shrubs/bushes. Spiders were collected with an aspirator from the net. Ground hand collecting ('below the knee') is active hand collection from ground to knee level and requires kneeling to access specimens. This method was used to collect spiders from the ground, leaf litter, logs, small holes in trees, bark crevices, stones and the lowest vegetation. Aerial hand collecting ('above the knee') is hand collection from knee height to as high as one can reach. This method was used for web-building and plant-dwelling spiders on taller herbs, shrubs, trees, foliage and underneath bark. For both hand-collecting methods glass vials and aspirators were used to sample spiders. These were then transferred into vials containing $70 \%$ ethanol.

Pitfall traps $9 \mathrm{~cm}$ in diameter and $10 \mathrm{~cm}$ deep were used to sample epigaeic spiders and filled with $100 \mathrm{ml}$ of propylene glycol. During each of the two sampling events, 25 pitfall traps were set 
up at each of the sites and left open for ten days for a total of 4000 trap nights over the whole study. Pitfall traps were clustered in five groups of five traps each within a site and spaced $10 \mathrm{~m}$ apart within each group. Groups were spaced $50 \mathrm{~m}$ apart, each group representing a replicate.

\section{Treatment of specimens}

In the laboratory only adult spiders were sorted and identified up to morphospecies level as objective species level identification of juvenile spiders poses a considerable taxonomic challenge. All adult spiders were then identified to species level by the third author, with the following exceptions: Salticidae (G.N. Azarkina Siberian Zoological Museum, Russia), Lycosidae (A. Russell-Smith, UK), Miturgidae (L. Lotz, National Museum, South Africa) and Corinnidae (C. Haddad, University of the Free State, South Africa). All voucher specimens were deposited in the National Collection of Arachnida (NCA) at the Plant Protection Research Institute of the Agricultural Research Council, Pretoria, South Africa.

\section{Statistical analysis}

Six species richness estimates (Chao1, Chao2, ACE, Jackknife1, Jackknife2, and Michaelis Menten), observed species richness, singletons and doubletons were calculated for each of the vegetation types and their four plant communities (sites) with 50 sample order randomizations in Estimate S v8, (Colwell 1994-2004). Curves were sample-based and rescaled to individuals (Gotelli \& Colwell 2001; Cardoso et al. 2008b). Sampling completeness (sensu Sørensen et al. 2002; Scharff et al. 2003; Cardoso et al. 2008) was calculated as the ratio of the observed number of species and Chao1. Coddington et al. (1996) defined sampling intensity as the ratio of total number of individuals (adults) to species which is considered a coarse, though not inaccurate measure of sampling effort. A survey is complete when the observed species asymptote and singletons tend to zero and sufficient to estimate species richness when estimates asymptote (Colwell \& Coddington 1994). We tested whether the randomized curves approached an asymptote by calculating the slope of the last segment of the curve (sensu Cardoso et al. 2008b): slope $=1 /(n S n S \pm 1)$; where $n S=$ final number of individuals for each curve (corresponding to the total richness value $S$ ) and $n S \pm 1=$ number of individuals corresponding to the point in the curve where the final single species was added or subtracted to $S$ (corresponding to a richness value of $S \pm 1$ ).

The data were fitted to a lognormal distribution using the methods described by Longino et al. (2002) and Scharff et al. (2003). Coddington et al. (2009) point to the importance of including this distribution when undersampling is severe.

Only four (one experienced arachnologist and three inexperienced) collectors collected more than 25 samples each and only their results are included in the analysis of the collector effect. The effect of the time of day was analysed with reference to two classifications: morning (before 12:00 vs afternoon (after 12:00) and early morning (07:00-10:00) and late afternoon (15:00) vs midday (10:00-15:00). The data were log-transformed to reduce heteroscedasticity and inspected for normality with the Kolmogorov-Smirnov (Lilliefors) test. If normal, average species richness and number of adult spiders were compared with ANOVA and post hoc comparisons of operators responsible for significant differences were done with Fisher's LSD multiple-comparisons test (SYSTAT 12). The samples collected varied between treatments, namely collectors and time of day, and were therefore rarefied to the number of samples of the treatment with lowest number of samples. This was repeated twice to allow for the effects of randomly excluding samples. The effect of season, collectors, and methods on species composition was assessed by constructing Bray-Curtis similarity matrices for each of the factors which were subjected to the non-parametric analysis permutation procedure, namely analysis of similarities (ANOSIM) in Primer v.6 (Clarke \& Gorley 2006), that generates a test statistic $(R)$ reflecting the observed differences between factors. This test statistic varies between minus one and one; the difference between factors increases as $R$ approaches one. The permutation test allows for tests of significance.

Inventory efficiency is often evaluated with reference to accumulation curves where the steepest curves are the most optimal. Cardoso (2009) developed an iterative process that optimizes the slope of a curve, i.e. complementarity of samples, for any mix of samples that were taken with different methods. This process was applied to each of the vegetation types with the aim of calculating the number of samples per method that maximizes the species richness and finds common results between vegetation types. A standardized protocol should also have stopping rules and Cardoso 


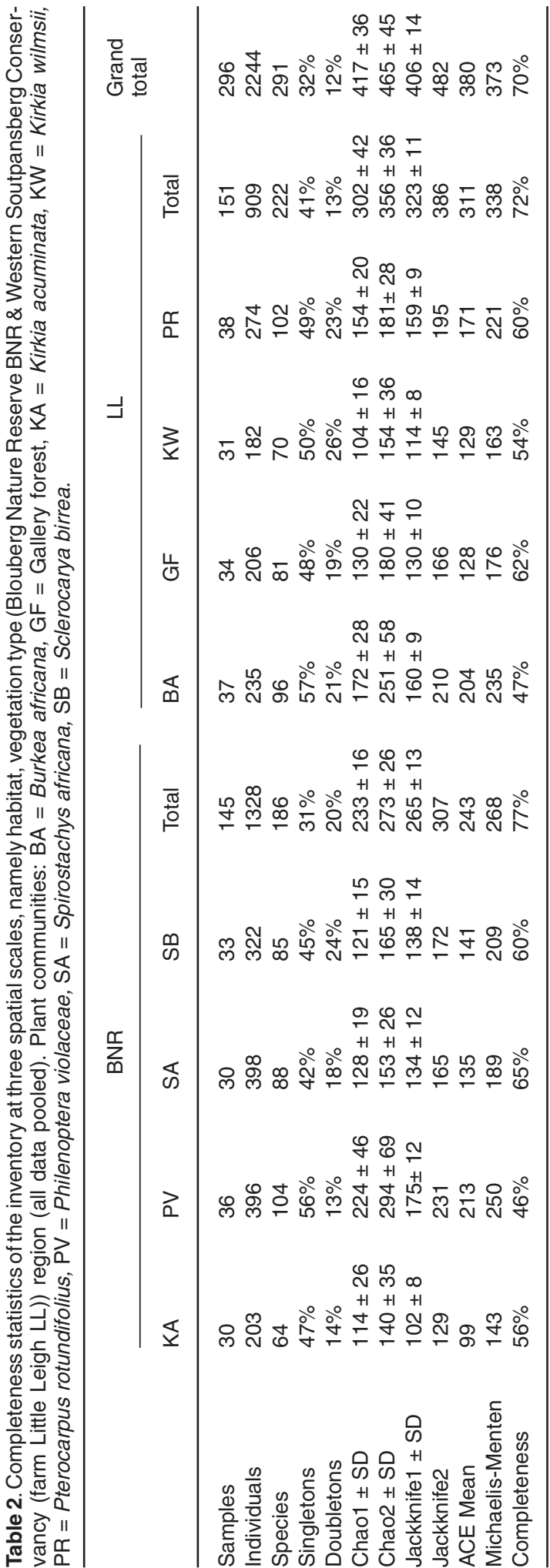

(2009) identified three categories: 'reasonable' $50 \%$, 'comprehensive' 70-80\% and 'exhaustive' $(90-100 \%)$. We identified the optimal protocol for our vegetation types that would target $50 \%$ and $80 \%$ of the estimated species.

\section{RESULTS}

The inventory produced a total of 297 samples distributed over seven days in November $(n=151)$ and seven days in March $(n=146)$ and 200 pitfall traps left open for 20 days, which together yielded 2244 adults of 291 species, 161 genera and 44 families (Appendix 1). Thirty-two per cent of the species were singletons and $12 \%$ were doubletons. The Salticidae was the most diverse family, with 42 species, followed by Thomisidae (28), Gnaphosidae (27) and Theridiidae (26). The most diverse genus was Oxyopes Latreille, 1804 (Oxyopidae, 12 spp.), followed by Asemesthes Simon, 1887 (Gnaphosidae, 8 spp.) and Thomisus Walkenaer, 1805 (Thomisidae, 7 spp.). The gnaphosid, Zelotes scrutatus (O.P.-Cambridge, 1872), was the most abundant species ( $n=147$ individuals), but not particularly dominant as it accounted for only $5 \%$ of all the adult spiders and it was closely followed by another gnaphosid, Asemesthes pallidus Purcell, 1908, with $n=$ 102 individuals $(4.5 \%$ of the whole assemblage).

Based on identifications of specialists, ten species and two genera are possibly new (Appendix 1). Since there had been no prior sampling in these areas, all species are new records for the BNR and the farm Little Leigh.

\section{Inventory completeness and species richness estimates}

Inventory completeness within the sites varied between $46 \%$ at the Philenoptera violaceae site and $65 \%$ at the Kirkia acuminata site and species richness estimates (Chao1) varied between 104 and 224 (Table 2). Inventory completeness for the two vegetation types was comprehensive $(>70 \%)$. The slopes of the last segment of Chao1 (0.016) and Chao2 (0.001) for the BNR vegetation type approached an asymptote whereas the lowest slope for the WSC vegetation type was that of the Michaelis-Menten estimate (0.06). The observed data fit the lognormal distribution well $\left(R^{2}=0.987\right)$, the modal 

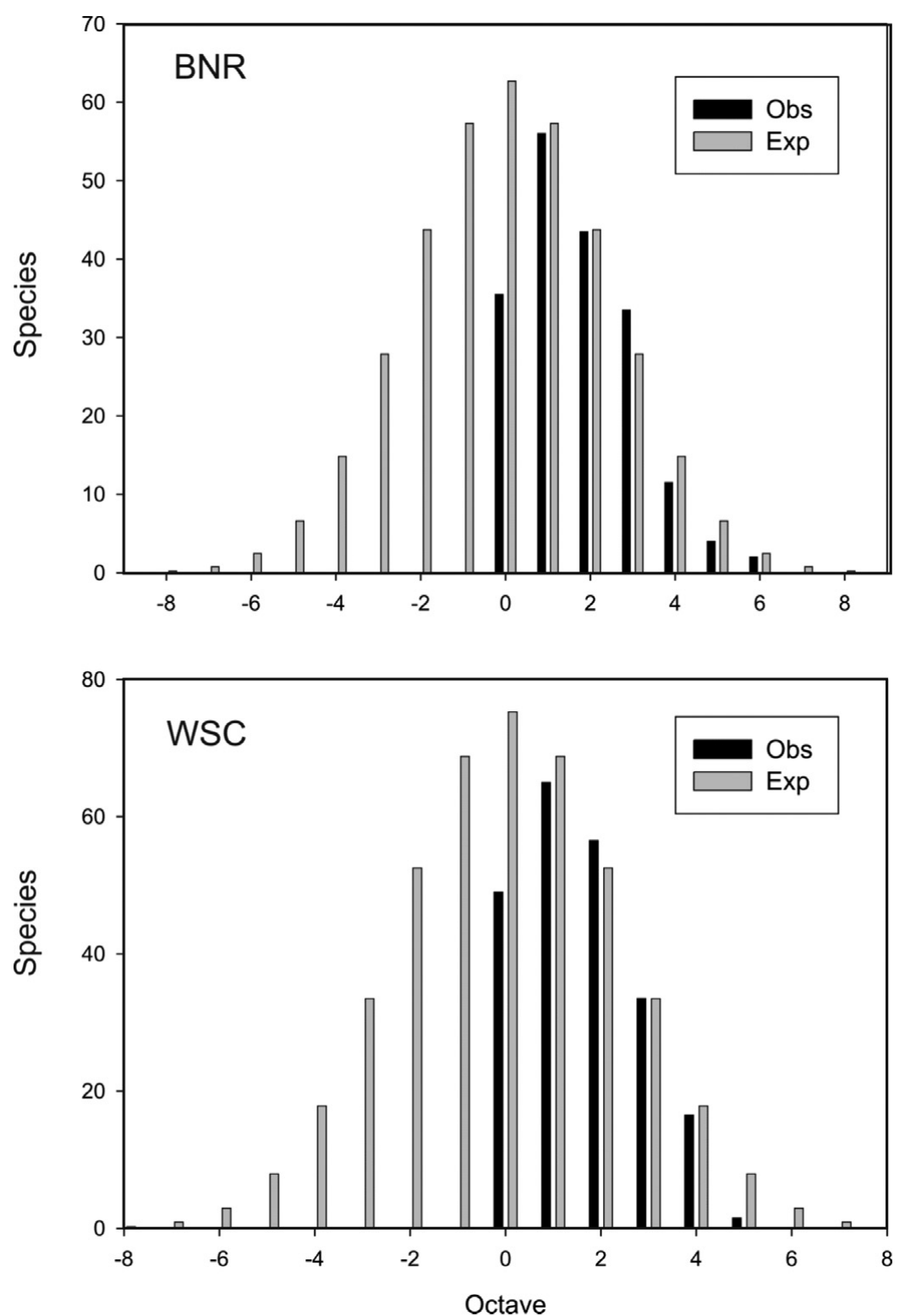

Fig. 2. Lognormal fit $\left(R^{2}=0.978\right)$ to data in Table 1. Predicted community size is 370 species for BNR and 445 for WSC.

octave $S_{0}$ for BNR is $62.7 \pm 10.6$, the variance term 'a' was $0.3 \pm 0.05$ with an estimated richness of 370. In contrast, the modal octave $S_{0}$ for WSC is $75.2 \pm 16.6$, the variance term 'a' was $0.31 \pm 0.07$ with an estimated richness of 445 (Fig. 2). Non-parametric richness estimates in the BNR vegetation type were between 233 and 307 and those of the WSC vegetation type were between 302 and 386. In both instances the Chao1, Jackknife and ACE gave the lowest estimates whereas Chao2 and Michaelis-Menten consistently gave the highest estimates (Table 2).

Overall sample intensity (specimens/species) was 7.6. This varied from 2.34 for aerial sampling to 5.2 for sweep netting (Table 3 ). This excludes pitfall trapping as samples were pooled for this method. Overall, samples averaged at 7.44 individuals and 3.97 species. Aerial sampling yielded the fewest individuals per sample at 2.42 and sweep netting the most, 7.81 (Table 3 ). The fewest 
Table 3. A comparison of the observed and estimated number of species targeted by the various collecting methods used during surveys. $A=$ aerial collecting, $B B=$ branch beating, $\mathrm{G}$ = ground collecting, LS = leaf litter sifting; $\mathrm{SN}=$ sweep netting, $\mathrm{P}=$ pitfall traps. Samples from pitfall traps were pooled for each of the eight plant communities

\begin{tabular}{lllllll}
\hline & A & G & BB & LS & SN & P \\
\hline No. of samples & 65 & 66 & 66 & 45 & 53 & 8 \\
No. of individuals & 162 & 458 & 478 & 232 & 414 & 500 \\
$\begin{array}{l}\text { Average individuals/ } \\
\text { sample }\end{array}$ & 2.42 & 6.94 & 7.34 & 5.21 & 7.81 & 61.6 \\
Singletons & 34 & 43 & 50 & 31 & 35 & 30 \\
Doubletons & 13 & 26 & 16 & 17 & 9 & 12 \\
Observed species & 66 & 105 & 118 & 67 & 78 & 68 \\
richness & & & & & & \\
Sample intensity & 2.34 & 4.3 & 4 & 3.34 & 5.2 & 7.25 \\
Cha01 & 110 & 141 & 196 & 95 & 146 & 102 \\
Completion (\%) & 60 & 74.4 & 60 & 71 & 53 & 67 \\
\hline
\end{tabular}

species per sample, 1.8, was once again recorded by aerial sampling, whereas beating yielded the most species, 5.58 , per sample.

\section{Effect of collectors}

On average, the experienced collector caught more species: 4.8 species per sample, compared to the 3.7 species of the collector that caught the least. However, these difference were not significant $\left(F_{3,27}=1.46, P=0.231 ; F_{3,27}=1.078, P=0.362\right)$. A similar pattern can be observed for the number of individuals caught per sample, with the experi-
Table 4. Inventory data of spiders sampled by season at Blouberg Nature Reserve and Western Soutpansberg Conservancy (Little Leigh), pooled for the two sites.

\begin{tabular}{lrr}
\hline & November 2005 & March 2006 \\
\hline No. of samples & 151 & 146 \\
No. of specimens & 1373 & 871 \\
Observed no. of species & 203 & 175 \\
Singletons & 79 & 59 \\
Doubletons & 34 & 44 \\
Chao1 & 295 & 215 \\
Completion (\%) & 68 & 81 \\
\hline
\end{tabular}

enced collector averaging at 7.8 individuals per sample as compared to the lowest yield of 5.7, but with no real significant differences between the number of individuals caught by the collectors $\left(F_{3,27}=0.428, P=0.733 ; F_{3,27}=0.225, P=0.879\right)$. There were also no significant differences between the composition of spider assemblages collected by the different collectors $(R=0.011, P=0.075)$.

\section{Diurnal effects}

Data analysed to test the effect of 'time of day' were not normally distributed after transformation. Therefore, the means were compared using the Mann-Whitney $U$-test. Although very small, there was an overall decrease in the number of spiders caught later in the day (Fig. 3) which resulted in a significant difference between samples taken in the morning (before 12:00) as compared to those

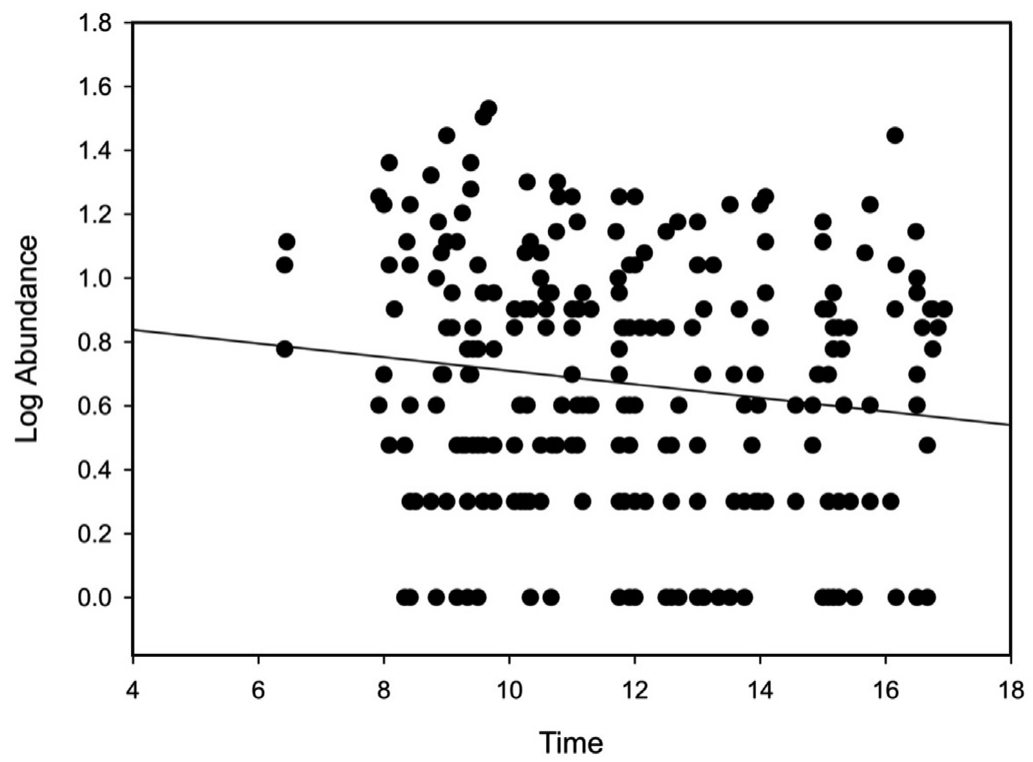

Fig. 3. Linear regression of number of specimens caught in a sample and time of day. 


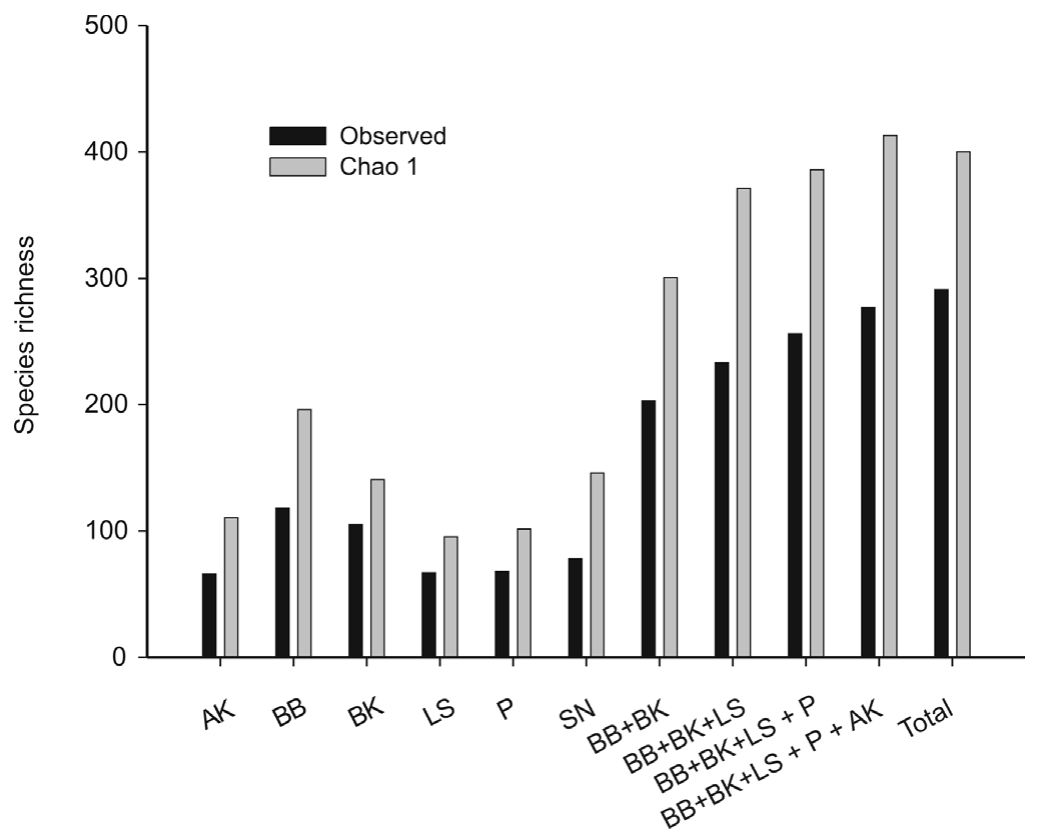

Fig. 4. Sample completion for all the collecting methods and combinations of methods that were the most productive. $A=$ aerial collecting, $B B=$ branch beating, $B K=$ ground collecting, $L S=$ leaf litter sifting; $S N=$ sweepnetting, $P=$ pitfall traps.

taken in the afternoon $(U=4907, P<0.005)$, but there was no difference between numbers caught during midday and the early morning/late afternoon treatments $(U=7446, P<0.817)$ which can be explained by the decrease in catch as the day progressed, something that could be ascribed to collector fatigue.

\section{Seasonal effects}

The November (2005) survey was substantially less complete than the survey in March (2006), $68 \%$ vs $81 \%$, even though the sampling efforts in the two seasons were essentially the same (Table 3 ). There was a small, but significant difference $(R=$ $0.073, P=0.001$ ) between the composition of the spider assemblages caught in the different seasons.

\section{Collecting methods}

The mean inventory completeness for all the methods was $64.2 \%$ (Fig. 4). Comparing the methods in terms of completeness, ground collection was the most complete at $74.4 \%$ and the other two most productive methods, leaf litter sifting and branch beating, had completeness percentages of $71 \%$ and $60 \%$, respectively. Branch beating was the most effective sampling technique, followed by ground collecting (Fig. 4). This is confirmed by the observation that branch beating had the most species unique to this method, (43), followed by ground hand collecting (34). Sweep netting yielded the lowest number of unique species, with only 14 . Although aerial sampling had the highest rate of species accumulation per individuals sampled, it yielded a much lower species richness when number of samples was the independent variable instead of individuals (Fig. 5). This is also evident when considering that 15 aerial samples had no adult spiders compared to five in leaf litter sifting, four in branch beating, and three each for ground collecting and sweep netting. There was a relatively large and significant difference in the spider assemblages targeted by the different methods $(R=0.214, P=0.001)$.

\section{An optimal and standardized protocol}

Based on the slopes of their accumulation curves, branch beating and ground searching were the most effective collecting methods. This was true for both vegetation types (Fig. 5). After 34 samples the balanced design (balanced representation of all the methods) targets $46 \%$ of the observed species in the BNR vegetation type and $42 \%$ of the WSC species compared to the $50 \%$ for the optimal design i.e. a design that maximizes the complementarity of samples that are sequentially added. When the design consisted of 76 samples the 

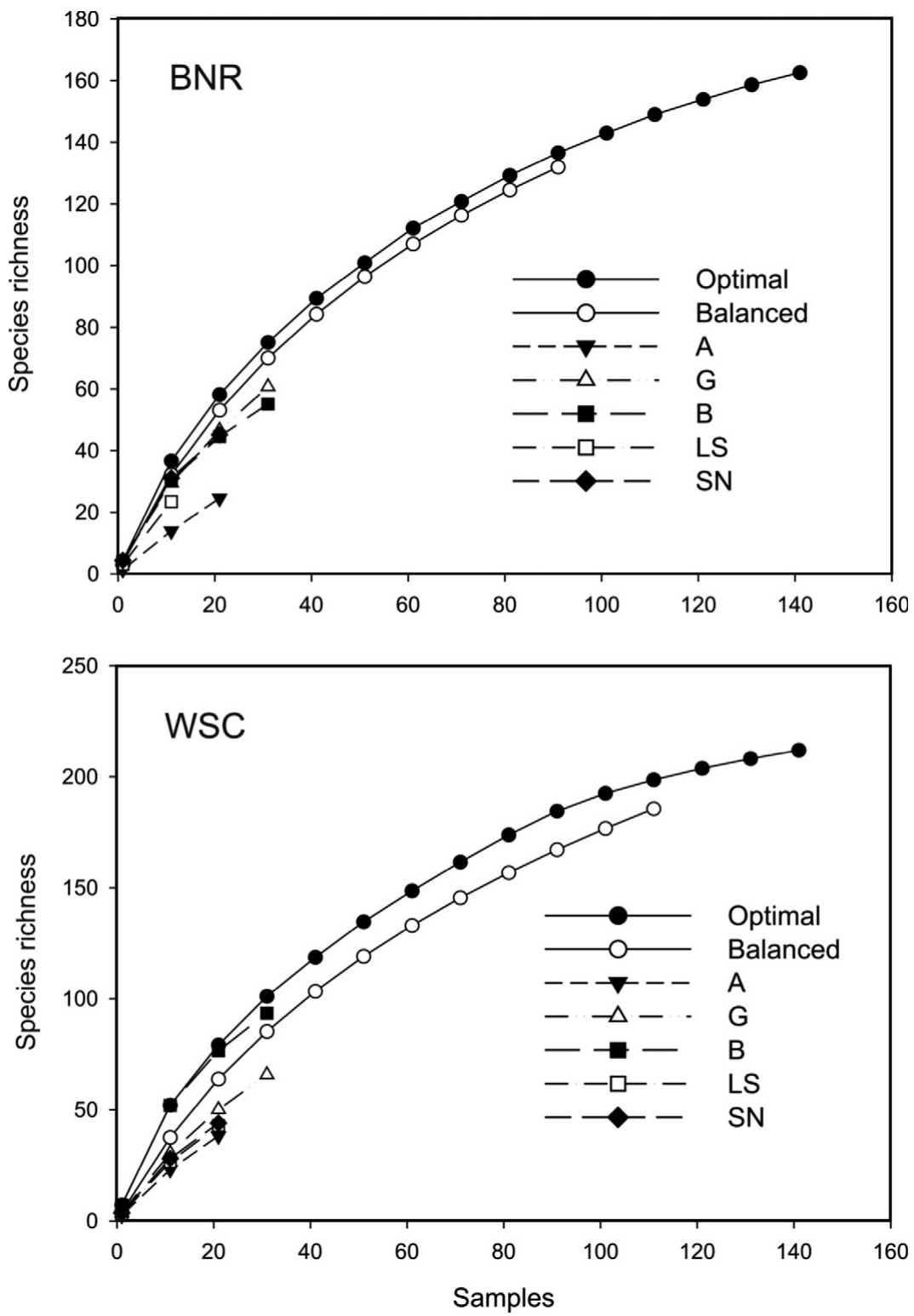

Fig. 5. Randomized species accumulation curves of the two sampled vegetation types. Optimized and balanced curves give average richness for optimal and even mixes, respectively.

balanced designs sampled $72 \%$ and $71 \%$ of the observed species in the BNR and WSC vegetation types, respectively, compared to the $80 \%$ for the optimal design. Table 5 lists the optimal combinations of methods for the two vegetation types. In both instances two-thirds of the samples were assigned to branch beating and ground collecting. The relative contribution they made to the design varied between the two vegetation types, with beating being more important at WSC and ground searching dominating at BNR. The remainder was assigned to leaf litter sifting and sweep netting. Only in one instance were samples assigned to aerial searching (Table 5).

\section{DISCUSSION}

This study is a first attempt at estimating savanna spider diversity in a standardized way that is comparable with studies in other regions of the world. Although inventory completeness for the 
Table 5. Proposed sub-protocols that simultaneously optimize sampled richness and their application in two tested vegetation types at Blouberg Nature Reserve (BNR) and Western Soutpansberg Conservancy (Little Leigh LLWSC). $\mathrm{A}=$ aerial collecting, $\mathrm{BB}=$ branch beating, $\mathrm{G}$ = ground collecting, $\mathrm{LS}=$ leaf litter sifting; $\mathrm{SN}=$ sweep netting; $\mathrm{S}=$ observed species richness, $\mathrm{S}^{*}=$ estimated species richness.

\begin{tabular}{clrrrrrrr}
\hline \multirow{2}{*}{ Samples } & Vegetation type & A & G & BB & LS & SN & $\%$ \% & \% * \\
\hline \multirow{2}{*}{34} & BNR & 0 & 12 & 10 & 4 & 8 & 50 & 36 \\
& LLWSC & 0 & 4 & 19 & 9 & 2 & 50 & 34 \\
\multirow{2}{*}{76} & BNR & 4 & 32 & 20 & 9 & 11 & 80 & 56 \\
& LLWSC & 0 & 27 & 32 & 14 & 3 & 80 & 53 \\
\hline
\end{tabular}

sites was rather low, inventories of the two vegetation types could be considered 'comprehensive' with $>70 \%$ inventory completeness (Cardoso 2009). This two-week survey represents a snapshot of true diversity. Spider richness should be higher than the estimates as the adults of some species were not present and some species could not be caught with the methods employed (Cardoso et al. 2008b). In Africa, one other study applied the Coddington protocol in the subcanopy of Afromontane forests of Tanzania and estimated spider richness at 160-190 (Sørensen et al. 2002). Although semi-quantitative, another study by Whitmore et al. (2002), evaluated the effect of methods and seasons on results for a Savanna Biome, but did not use time as a surrogate of effort and did not attempt to estimate richness.

As the Michaelis-Menten estimator had the lowest slope for the least complete inventory (WSC), this estimator could be useful as an estimate for inventories with lower inventory completeness estimates. Toti et al. (2000) reached a similar conclusion based on their structured survey in Appalachian grass bald and heath bald, which had inventory completeness less than $70 \%$. Chao 1 and Chao2 performed the best for the more complete survey in the BNR. This is consistent with Cardoso et al. (2008b), suggesting that these two estimators perform better than Michaelis-Menten when inventories are very intensive with high completeness values. The high singleton count of $32 \%$ conforms to the average singleton count reported in 72 other studies throughout tropical regions of the world (Coddington et al. 2009). Coddington et al. (2009) argued that no biological hypothesis could explain the high incidence of singletons in the surveys they examined, and that the default explanation of undersampling should therefore be preferred. This points to the prevalence of undersampling in all these surveys and that non-parametric richness estimates underestimate true richness by $35 \%$. The fit of the data in this study to a lognormal distribution suggests that the non-parametric species richness estimates are $30-40 \%$ less than those derived from parametric estimation (lognormal distribution), with an inventory completeness of only $50 \%$.

As has been shown in other studies (Cardoso et al. 2008b; Lovell et al. 2009), the methods employed in this protocol are not compromised by collector experience. This opens up the real possibility to develop a protocol that has broad applicability. As in several other studies, the suite of methods employed is the single most important factor in determining the abundance, species richness and composition of spiders sampled.

Spider abundance and richness was highest in November (early summer) as compared to autumn (March) in both of the vegetation types. This conforms with previous findings (Whitmore et al. 2002) and probably is the result of subadults that mature during the winter months and attain adulthood in early summer when mating occurs, by late summer most of the adults have died or have been swamped by juveniles. This is confirmed by a study that included juveniles: $34 \%$ of the spiders caught were adult in early summer, whereas this figure went down to $25 \%$ later in the season (Foord et al. 2008). The proportion of adults in that study also conformed to the results of several other studies (Coddington et al. 1991; Coddington et al. 1996; Scharff et al. 2003).

If resources are available it would make sense to include all the methods in a study. But, when equal sampling effort is assigned to different methods it is assumed that they are equally efficient or they target faunal partitions that contain equal numbers of species with the same abundance distributions (Coscaron et al. 2009). This assumption is flawed and a good sampling design would compensate for differences in species richness and abundance in the different compartments. Resources should be focused on a design that maximizes the difference in spider species caught. 
An optimized protocol for very low $(\sim 30 \%$ inventory completeness) to low ( $\sim 50 \%$ inventory completion) sampling efforts would exclude or assign less effort to aerial searching because it is highly inefficient (Table 5). This conclusion might not be applicable to other biomes such as grasslands and forests. Excluding this method completely would also not be advisable. An alternative would be to allocate aerial searching to more experienced collectors that know which microhabitats to target. Beating was shown to target the most species, followed by ground collecting and leaf litter sifting, and these methods comprise the bulk of the proposed protocol. This contrasts with work in the Iberian Peninsula, where ground searching was the least effective method (Cardoso 2009). Although sweep netting sampled more adult individuals, it overlapped considerably with beating. Contrary to some studies (Cardoso 2009), pitfall trapping was the method that contributed the smallest amount of unique species but this pattern is consistent with Whitmore et al.'s (2002) results in a Savanna Biome. The poor performance of pitfall traps in this study could also be the result of including leaf litter sifting. The species composition of this method and ground collecting overlapped significantly with that of the pitfall catches. The wider significance of this result should however consider that the efficiency of any particular method may vary between habitats, vegetation types or biogeographic region as a result of the relative dominance of different spider taxa and differences in vegetation structure.

Three aspects need further investigation if a comprehensive protocol is to be developed for the Savanna Biome. Firstly, sampling was not done at night in this study. Although anecdotal evidence for the biome suggests otherwise, a quantitative assessment is required to test whether there is a difference in spider assemblages targeted during the night as compared to the day. Secondly, Cardoso (2008b) suggested pooling pitfall traps to make it more comparable to the efforts of the time-based methods where four pitfall traps are considered to be equivalent to one-person hour of work in terms of digging and setting up the trap as well as collecting it. This will enable the inclusion and evaluation of pitfall samples as part of an optimal design. Thirdly, although our inventory completeness was $>70 \%$, an exhaustive survey in 1 ha of savanna biome would provide a credible and comparable test of the sampling design proposed in this study.

\section{ACKNOWLEDGEMENTS}

We would like to thank Norbert Hahn for his assistance in the field and access to the farm Little Leigh. Tony Russell-Smith, Galina Azarkina, Leon Lotz and Charles Haddad are thanked for species determinations and discussions. Pfarelo Tshivhandekano, Fhulufhelo Maanda, Ben van der Waal, Freedom Mbedzi, Innocent Sinthumule, Abeda Dawood, Dawid Spengler, Sandra Spengler, Sydney Mafundza and Vhuhwavho Gelebe assisted in the field as collectors. Comments by three reviewers improved the manuscript. This research was funded by the University of Venda and a NRF grant (GUN 2054390) to the second author. S.H.F. also acknowledges support from the DST-NRF Centre of Excellence for Invasion Biology.

\section{REFERENCES}

CARDOSO, P. 2009. Standardization and optimization of arthropod inventories - the case of Iberian spiders. Biodiversity and Conservation 18: 3949-3962.

CARDOSO, P., GASPAR, C., PEREIRA, L.C., SILVA, I., HENRIQUES, S.S., SILVA, R.R. \& SOUSA, P. 2008a. Assessing spider species richness and composition in Mediterranean cork oak forests. Acta Oecologia 33: 114-127.

CARDOSO, P., HENRIQUES, S.S., GASPAR, C.S., CRESPO, L.C., CARVALHO, R., SCHMIDT, J.B., SOUSA, P. \& SZÜTS, T. 2009. Species richness and composition assessment of spiders in a Mediterranean scrubland. Journal of Insect Conservation 12: 45-55.

CARDOSO, P., SCHARFF, N., GASPAR, C.S., HENRIQUES, S.S., CARVALHO, R., CASTRO, P.H., SCHMIDT, J.B., SILVA, I., SZUTS, T., DE CASTRO, A. \& CRESPO, L.C. 2008b. Rapid biodiversity assessment of spiders (Araneae) using semi-quantitative sampling: a case study in a Mediterranean forest. Insect Conservation and Diversity 1: 71-84.

CLARKE, K.R. \& GORLEY, R.N. 2006. PRIMER v6: User Manual/Tutorial. PRIMER-E, Plymouth.

CODDINGTON, J.A., AGNARSSON, I., MILLER, J.A., KUNTER, M. \& HORMIGA, G. 2009. Undersampling bias: the null hypothesis for singleton species in tropical arthropod surveys. Journal of Animal Ecology 78: $573-584$.

CODDINGTON, J.A., GRISWOLD, C.E. \& DAVILA, D.S. 1991. Designing and testing sampling protocols to estimate biodiversity in tropical ecosystems. In: The Unity of Evolutionary Biology: Proceedings of the Fourth International Congress of Systematics and Evolutionary Biology, (ed.) E.C. Dudley, pp. 44-60. Dioscorides Press, Portland.

CODDINGTON, J.A., YOUNG, L.H. \& COYLE, F.A. 1996. Estimating spider species richness in a southern Appalachian Cove Hardwood forest Journal of Arachnology 24: 111-128.

COLWELL, R. \& CODDINGTON, J.A. 1994. Estimating terrestrial diversity through extrapolation. Philosophical Transactions of the Royal Society of London B 345: 101-108. 
COLWELL, R.K. 1994-2004. Estimate S: Statistical estimation of species richness and shared species from samples. Version 7. Persistent URL: http://vice-roy. eeb.uconn.edu/estimates

COSCARON, M.C., MELO, C., CODDINGTON, J.A. \& CORRONCA, J. 2009. Estimating biodiversity: a case study on true bugs in argentinian wetlands. Biodiversity and Conservation 18: 1491-1507.

FOELIX, R. F. 1996. Biology of Spiders. Oxford University Press, Oxford.

FOORD, S.H., DIPPENAAR-SCHOEMAN, A.S. \& VAN DER MERWE, M. 2002. A check list of the spider fauna of the Western Soutpansberg, South Africa (Arachnida: Araneae). Koedoe 45: 35-43.

FOORD, S.H., MAFADZA, M., DIPPENAARSCHOEMAN, A.S. \& VAN RENSBURG, B.J. 2008. Micro-scale heterogeneity of spiders (Arachnida: Araneae) in the Soutpansberg, South Africa: a comparative survey and inventory in representative habitats African Zoology 43: 156-174.

GOTELLI, N.J. \& COLWELL, R. 2001. Quantifying biodiversity: procedures and pitfalls in the measurement and comparison of species richness. Ecology Letters 4: 379-391.

HADDAD, C.R. 2009. Vendaphaea, a new dark sac spider genus apparently endemic to the Soutpansberg Mountains, South Africa (Araneae: Corinnidae). African Invertebrates 50: 269-278.

HUBER, B.A. 2003. Southern African pholcid spiders: revision and cladistic analysis of Quamtana gen. nov. and Spermophora Hentz (Araneae: Pholcidae), with notes on male-female covariation. Zoological Journal of the Linnean Society 139: 477-527.

JOCQUÉ, R. 2008. A new candidate for a Gondwanaland distribution in Zodariidae (Araneae): Australutica in Africa. Zookeys 1: 59-66.
LONGINO, J.T., CODDINGTON, J.A. \& COLWELL, R. 2002. The ant fauna of a tropical rain forest: estimating species richness three different ways. Ecology 83: 689-702.

LOTZ, L.N. 2002. A revision of the Afrotropical genus Cheiramiona (Araneae: Miturgidae: Eutichurinae). Annals of the Museum Royale Africa Centrale 290: 39-86.

LOVELL, S., HAMER, M., SLOTOW, R. \& HERBERT, D. 2009. An assessment of the use of volunteers for terrestrial invertebrate biodiversity surveys. Biodiversity and Conservation 18: 3295-3307.

MAGURRAN, A.E. 2004. Measuring Biological Diversity. Blackwell Publishing, Oxford,.

MOSTERT, T.H.C., BREDENKAMP, G.J., KLOPPER, H.L., VERWEY, C., MOSTERT, R.E. \& HAHN, N. 2008. Major vegetation types of the Soutpansberg Conservancy and the Blouberg Nature Reserve, South Africa. Koedoe 50: 32-48.

SCHARFF, N., CODDINGTON, J.A., GRISWOLD, C.E., HORMIGA, G. \& BJORN, P. 2003. When to quit? Estimating spider species richness in a northern European deciduous forest. Journal of Arachnology 31: 246-273.

SØRENSEN, L.I., CODDINGTON, J.A. \& SCHARFF, N.J. 2002. Inventorying and estimating subcanopy spider diversity using semiquantitative sampling methods in an Afromontane forest. Environmental Entomology 31: 319-330.

TOTI, D. S., COYLE, F.A. \& MILLER, J.A. 2000. A structured inventory of Appalachian grass bald and heath bald spider assemblages and a test of species richness estimator performance. Journal of Arachnology 28: 329-345.

WHITMORE, C., SLOTOW, R., CROUCH, T.E. \& DIPPENAAR-SCHOEMAN, A.S. 2002. Diversity of spiders (Araneae) in a Savanna reserve, Northern Province, South Africa. Journal of Arachnology 30: 344-356.

Responsible Editor: M.D. Picker 
Appendix 1. Checklist of spiders caught at Blouberg Nature Reserve (BNR) and Farm Little Leigh (WSC). Plant communities: $\mathrm{BA}=$ Burkea africana, $\mathrm{GF}=$ Gallery forest, $\mathrm{KA}=$ Kirkia acuminata, $\mathrm{KW}=$ Kirkia wilmsii, $\mathrm{PR}=$ Pterocarpus rotundifolius, $\mathrm{PV}=$ Philenoptera violaceae, $\mathrm{SA}=$ Spirostachys africana, $\mathrm{SB}=$ Sclerocarya birrea .

\begin{tabular}{|c|c|c|c|c|c|c|c|c|c|c|}
\hline \multirow[t]{2}{*}{ Family } & \multirow[t]{2}{*}{ Genus } & \multirow[t]{2}{*}{ Species } & \multicolumn{4}{|c|}{ BNR } & \multicolumn{4}{|c|}{ Little Leigh } \\
\hline & & & KA & PV & SB & SA & BA & GF & KW & PR \\
\hline \multirow[t]{3}{*}{ Agelenidae } & Benoitia & Benoitia ocellata (Pocock, 1900) & 0 & 0 & 0 & 1 & 0 & 0 & 0 & 0 \\
\hline & Mistaria & Mistaria leucopyga (Pavesi, 1883) & 3 & 0 & 2 & 2 & 0 & 0 & 0 & 1 \\
\hline & Olorunia & Olorunia punctata Lehtinen, 1967 & 0 & 0 & 1 & 1 & 0 & 0 & 0 & 0 \\
\hline Amaurobiidae & Chresiona & Chresiona invalida (Simon, 1898) & 0 & 0 & 0 & 0 & 0 & 1 & 0 & 0 \\
\hline \multirow[t]{2}{*}{ Ammoxenidae } & Ammoxenus & Ammoxenus psammodromus Simon, 1910 & 0 & 53 & 0 & 0 & 0 & 0 & 7 & 0 \\
\hline & Rastellus & Rastellus florisbad Platnick \& Griffin, 1990 & 0 & 0 & 1 & 0 & 0 & 0 & 0 & 0 \\
\hline \multirow[t]{21}{*}{ Araneidae } & Araneilla & Araneilla sp. 1 & 0 & 9 & 0 & 0 & 7 & 0 & 4 & 1 \\
\hline & Araneus & Araneus apricus (Karsch, 1884) & 0 & 0 & 0 & 0 & 0 & 1 & 1 & 0 \\
\hline & & Araneus holzapfeli Lessert, 1936 & 2 & 4 & 4 & 0 & 1 & 3 & 2 & 3 \\
\hline & & Araneus legonensis Grasshoff \& Edmunds, 1979 & 0 & 0 & 0 & 0 & 0 & 1 & 0 & 0 \\
\hline & Argiope & Argiope australis (Walckenaer, 1805) & 1 & 0 & 0 & 0 & 0 & 0 & 2 & 0 \\
\hline & Cyphalonatus & Cyphalonatus larvatus (Simon, 1881) & 0 & 1 & 0 & 0 & 1 & 1 & 0 & 0 \\
\hline & Cyrtophora & Cyrtophora citricola (Forsskål, 1775) & 2 & 0 & 2 & 1 & 3 & 0 & 1 & 2 \\
\hline & & Araneidae sp. 1 & 0 & 0 & 0 & 1 & 0 & 0 & 0 & 0 \\
\hline & & Araneidae sp. 2 & 0 & 0 & 2 & 1 & 0 & 0 & 0 & 0 \\
\hline & & Araneidae sp. 3 & 0 & 0 & 1 & 0 & 0 & 0 & 0 & 0 \\
\hline & & Araneidae sp. 5 & 0 & 0 & 0 & 0 & 0 & 1 & 0 & 0 \\
\hline & Hypsosinga & Hypsosinga sp. 1 & 0 & 1 & 0 & 0 & 2 & 0 & 0 & 1 \\
\hline & & Hypsosinga lithyphantoides Caporiacco, 1947 & 0 & 6 & 1 & 1 & 3 & 0 & 0 & 1 \\
\hline & Nemoscolus & Nemoscolus cotti Lessert, 1933 & 0 & 4 & 0 & 0 & 0 & 0 & 0 & 0 \\
\hline & & Nemoscolus elongatus Lawrence, 1947 & 0 & 4 & 3 & 3 & 2 & 0 & 0 & 0 \\
\hline & & Nemoscolus sp. 3 & 0 & 7 & 0 & 0 & 0 & 1 & 0 & 0 \\
\hline & & Nemoscolus tubicola (Simon, 1887) & 0 & 0 & 1 & 0 & 1 & 0 & 0 & 2 \\
\hline & Neoscona & Neoscona blondeli (Simon, 1885) & 1 & 1 & 2 & 2 & 1 & 0 & 0 & 3 \\
\hline & & Neoscona sp. 3 & 0 & 0 & 0 & 2 & 0 & 0 & 0 & 0 \\
\hline & & Neoscona subfusca (C.L. Koch, 1837) & 1 & 2 & 5 & 1 & 2 & 1 & 1 & 1 \\
\hline & Pronous & Pronous sp. 1 & 1 & 0 & 0 & 0 & 0 & 0 & 0 & 0 \\
\hline Atypidae & Calommata & Calommata simoni Pocock, 1903. & 0 & 1 & 0 & 0 & 0 & 0 & 0 & 0 \\
\hline Barychelidae & Pisenor & Pisenor notius Simon, 1889 & 1 & 1 & 0 & 0 & 0 & 0 & 11 & 0 \\
\hline Caponiidae & Caponia & Caponia chelifera Lessert, 1936 & 0 & 0 & 0 & 1 & 0 & 0 & 0 & 0 \\
\hline Clubionidae & Clubiona & Clubiona abbajensis Strand, 1906 & 0 & 0 & 0 & 0 & 1 & 0 & 1 & 0 \\
\hline \multirow[t]{7}{*}{ Corinnidae } & Cambalida & Cambalida coriacea Simon, 1909 & 0 & 0 & 0 & 0 & 0 & 3 & 1 & 0 \\
\hline & Copa & Copa flavoplumosa Simon, 1885 & 0 & 0 & 0 & 0 & 1 & 4 & 0 & 0 \\
\hline & Fuchiba & Fuchiba aquilonia Haddad \& Lyle, 2008 & 0 & 0 & 0 & 0 & 1 & 0 & 0 & 0 \\
\hline & Graptartia & Graptartia tropicalis Haddad, 2004 & 0 & 0 & 0 & 3 & 0 & 0 & 0 & 0 \\
\hline & Orthobula & Orthobula radiata Simon, 1897 & 0 & 1 & 0 & 1 & 1 & 0 & 0 & 6 \\
\hline & Thysanina & Thysanina serica Simon, 1910 & 0 & 0 & 0 & 0 & 0 & 0 & 0 & 1 \\
\hline & & Thysanina transversa Lyle \& Haddad, 2006 & 0 & 0 & 0 & 0 & 1 & 4 & 1 & 0 \\
\hline Cyrtaucheniidae & Ancylotrypa & Ancylotrypa sp. 1 & 0 & 0 & 0 & 1 & 0 & 0 & 0 & 0 \\
\hline \multirow[t]{3}{*}{ Dictynidae } & Archaeodictyna & Archaeodictyna sp. 1 & 1 & 10 & 1 & 8 & 0 & 7 & 16 & 1 \\
\hline & Dictyna & Dictyna sp. 1 & 0 & 0 & 0 & 0 & 0 & 0 & 5 & 0 \\
\hline & Mashimo & Mashimo leleupi Lehtinen, 1967 & 0 & 7 & 2 & 3 & 0 & 4 & 10 & 0 \\
\hline Dipluridae & Allothele & Allothele malawi Coyle, 1984 & 0 & 0 & 0 & 0 & 0 & 1 & 0 & 0 \\
\hline Eresidae & Stegodyphus & Stegodyphus africanus (Blackwall, 1866) & 4 & 2 & 0 & 0 & 0 & 0 & 2 & 0 \\
\hline \multirow[t]{3}{*}{ Gnaphosidae } & Aneplasa & Aneplasa interrogationis Tucker, 1923 & 0 & 0 & 0 & 0 & 0 & 2 & 0 & 1 \\
\hline & Asemesthes & Asemesthes ceresicola Tucker, 1923 & 7 & 0 & 8 & 1 & 3 & 0 & 3 & 7 \\
\hline & & Asemesthes pallidus Purcell, 1908 & 7 & 27 & 28 & 34 & 1 & 2 & 0 & 3 \\
\hline
\end{tabular}


Appendix 1 (continued)

\begin{tabular}{|c|c|c|c|c|c|c|c|c|c|c|}
\hline \multirow[t]{2}{*}{ Family } & \multirow[t]{2}{*}{ Genus } & \multirow[t]{2}{*}{ Species } & \multicolumn{4}{|c|}{ BNR } & \multicolumn{4}{|c|}{ Little Leigh } \\
\hline & & & KA & PV & SB & SA & BA & GF & KW & PR \\
\hline & & Asemesthes paynteri Tucker, 1923 & 0 & 0 & 0 & 0 & 1 & 0 & 0 & 0 \\
\hline & & Asemesthes purcelli Tucker, 1923 & 0 & 0 & 2 & 0 & 7 & 0 & 0 & 0 \\
\hline & & Asemesthes reflexus Tucker, 1923 & 0 & 0 & 0 & 0 & 1 & 0 & 0 & 0 \\
\hline & & Asemesthes sp. 2 & 3 & 36 & 13 & 24 & 5 & 0 & 0 & 4 \\
\hline & & Asemesthes sp. 3 & 0 & 0 & 0 & 2 & 0 & 0 & 0 & 0 \\
\hline & & Asemesthes sp. 4 & 0 & 0 & 0 & 1 & 0 & 0 & 0 & 0 \\
\hline & Camillina & Camillina cordifera (Tullgren, 1910) & 0 & 2 & 1 & 8 & 0 & 0 & 0 & 4 \\
\hline & & Camillina sp. 1 & 0 & 8 & 0 & 2 & 0 & 1 & 0 & 2 \\
\hline & Echemus & Echemus erutus Tucker, 1923 & 0 & 4 & 0 & 4 & 0 & 0 & 0 & 0 \\
\hline & & Gnaphosinae sp. 1 & 0 & 0 & 0 & 0 & 0 & 1 & 0 & 0 \\
\hline & Nomisia & Nomisia auris (Tucker, 1923) & 0 & 1 & 0 & 1 & 1 & 0 & 0 & 9 \\
\hline & & Nomisia varia (Tucker, 1923) & 1 & 1 & 1 & 5 & 0 & 0 & 0 & 8 \\
\hline & Scotophaeus & Scotophaeus sp. 1 & 0 & 0 & 0 & 0 & 1 & 0 & 0 & 0 \\
\hline & Setaphis & Setaphis arcus Tucker, 1923 & 4 & 1 & 8 & 2 & 2 & 0 & 0 & 2 \\
\hline & & Setaphis bilinearis Tucker, 1923 & 1 & 1 & 0 & 0 & 2 & 0 & 0 & 4 \\
\hline & Upognampa & Upognampa sp. 1 & 0 & 0 & 0 & 1 & 0 & 0 & 0 & 0 \\
\hline & Xerophaeus & Xerophaeus aurariarum Purcell, 1907 & 1 & 0 & 0 & 0 & 0 & 0 & 0 & 1 \\
\hline & Zelotes & Zelotes caldarius (Purcell, 1907) & 0 & 1 & 1 & 0 & 1 & 0 & 0 & 0 \\
\hline & & Zelotes corrugatus (Purcell, 1907) & 7 & 1 & 1 & 2 & 0 & 0 & 0 & 0 \\
\hline & & Zelotes natalensis Tucker, 1923 & 0 & 0 & 0 & 1 & 0 & 2 & 2 & 0 \\
\hline & & Zelotes scrutatus (0.P-Cambridge, 1872) & 0 & 4 & 79 & 32 & 0 & 0 & 0 & 0 \\
\hline & & Zelotes tuckeri Roewer, 1951 & 1 & 0 & 5 & 1 & 1 & 0 & 0 & 0 \\
\hline Hersiliidae & Hersilia & Hersilia arborea Lawrence, 1928 & 3 & 0 & 0 & 0 & 0 & 0 & 0 & 0 \\
\hline & & Hersilia sericea Pocock, 1898 & 1 & 2 & 0 & 0 & 5 & 1 & 4 & 1 \\
\hline & & Hersilia setifrons Lawrence, 1928 & 8 & 0 & 4 & 0 & 0 & 0 & 0 & 0 \\
\hline Idiopidae & Ctenolophus & Ctenolophus fenoulheti Hewitt, 1913 & 0 & 0 & 0 & 1 & 0 & 0 & 0 & 0 \\
\hline & & Ctenolophus sp. 1 & 0 & 1 & 0 & 0 & 0 & 0 & 0 & 0 \\
\hline & & Ctenolophus sp. 2 & 0 & 0 & 1 & 1 & 0 & 0 & 0 & 0 \\
\hline & Idiops & Idiops sp. 1 & 0 & 0 & 0 & 1 & 1 & 0 & 0 & 0 \\
\hline Linyphiidae & Mecynidis & Mecynidis sp. 1 & 0 & 0 & 0 & 0 & 0 & 0 & 1 & 0 \\
\hline & Meioneta & Meioneta natalensis Jocqué, 1984 & 0 & 0 & 0 & 0 & 0 & 1 & 0 & 0 \\
\hline & & Meioneta sp. 1 & 0 & 0 & 8 & 0 & 0 & 2 & 1 & 0 \\
\hline & Metaleptyphantes & Metaleptyphantes perexiguus (Simon \& Fage, 1922) & 0 & 0 & 0 & 0 & 0 & 0 & 0 & 1 \\
\hline & Pelecopsis & Pelecopsis sp. possible new & 0 & 0 & 0 & 0 & 0 & 0 & 0 & 2 \\
\hline & & Erigoninae sp. 1 & 0 & 0 & 1 & 1 & 0 & 1 & 0 & 1 \\
\hline Liocranidae & Rhaeboctesis & Rhaeboctesis trinotatus Tucker, 1920 & 0 & 4 & 0 & 2 & 1 & 1 & 1 & 3 \\
\hline Lycosidae & Evippa & Evippa sp. 1 possible new & 0 & 1 & 9 & 0 & 0 & 0 & 0 & 0 \\
\hline & Evippomma & Evippomma squamulatum (Simon, 1898) & 14 & 9 & 16 & 23 & 0 & 0 & 0 & 27 \\
\hline & Hippasa & Hippasa elienae Alderweireldt \& Jocqué, 2005 & 0 & 0 & 0 & 0 & 0 & 0 & 0 & 1 \\
\hline & Minicosa & Minicosa neptuna Alderweireldt \& Jocqué, 2007 & 0 & 0 & 0 & 0 & 0 & 0 & 0 & 2 \\
\hline & Pardosa & Pardosa crassipalpis Purcell, 1903 & 0 & 1 & 0 & 0 & 0 & 0 & 0 & 0 \\
\hline & Proevippa & Proevippa albiventris (Simon, 1898) & 0 & 0 & 0 & 7 & 0 & 0 & 0 & 1 \\
\hline & & Proevippa cf fascicularis (Purcell, 1903) & 0 & 0 & 0 & 0 & 1 & 0 & 0 & 0 \\
\hline & & Proevippa sp. possible new. & 0 & 1 & 3 & 0 & 4 & 0 & 0 & 1 \\
\hline & & Hippasinae sp. 1 & 0 & 0 & 0 & 0 & 0 & 0 & 0 & 1 \\
\hline & & Lycosinae indet, sp. 1 & 1 & 0 & 0 & 2 & 0 & 0 & 0 & 3 \\
\hline & & Trochosinae indet. sp. 1 & 0 & 1 & 1 & 1 & 0 & 6 & 0 & 2 \\
\hline Mimetidae & Ero & Ero sp. 1 & 0 & 0 & 0 & 0 & 0 & 0 & 0 & 1 \\
\hline & Mimetus & Mimetus sp. 1 possible new & 0 & 0 & 0 & 0 & 0 & 1 & 0 & 0 \\
\hline
\end{tabular}


Appendix 1 (continued)

\begin{tabular}{|c|c|c|c|c|c|c|c|c|c|c|}
\hline \multirow[t]{2}{*}{ Family } & \multirow[t]{2}{*}{ Genus } & \multirow[t]{2}{*}{ Species } & \multicolumn{4}{|c|}{ BNR } & \multicolumn{4}{|c|}{ Little Leigh } \\
\hline & & & $\mathrm{KA}$ & PV & SB & SA & BA & GF & KW & PR \\
\hline \multirow[t]{5}{*}{ Miturgidae } & Cheiracanthium & Cheiracanthium angolensis Lotz, 2007 & 0 & 0 & 0 & 1 & 1 & 0 & 0 & 0 \\
\hline & & Cheiracanthium furculatum Karsch, 1879 & 0 & 0 & 1 & 0 & 4 & 0 & 0 & 2 \\
\hline & & Cheiracanthium sp. 1 cf. angolensis Lotz, 2007 & 0 & 0 & 1 & 0 & 0 & 0 & 0 & 0 \\
\hline & Cheiramiona & Cheiramiona krugerensis Lotz, 2002 & 0 & 0 & 0 & 0 & 1 & 1 & 0 & 0 \\
\hline & & Cheiramiona sp. 1 possible new & 0 & 0 & 0 & 0 & 7 & 0 & 14 & 8 \\
\hline Mysmenidae & & Mysmenidae sp. 1 & 0 & 0 & 0 & 0 & 0 & 7 & 0 & 0 \\
\hline Nemesiidae & Hermacha & Hermacha sp. 1 & 0 & 0 & 0 & 2 & 0 & 0 & 0 & 0 \\
\hline & & Hermacha sp. 2 & 0 & 0 & 23 & 0 & 0 & 0 & 0 & 0 \\
\hline Nephilidae & Nephila & Nephila fenestrata Thorell, 1859 & 0 & 0 & 2 & 2 & 2 & 8 & 2 & 4 \\
\hline & & Nephila senegalensis (Walckenaer, 1842) & 0 & 0 & 1 & 0 & 0 & 0 & 1 & 2 \\
\hline Oonopidae & & Oonopidae sp. 1 & 0 & 0 & 0 & 0 & 2 & 0 & 0 & 0 \\
\hline \multirow[t]{18}{*}{ Oxyopidae } & Hamataliwa & Hamataliwa kulczynskii (Lessert, 1915) & 3 & 1 & 7 & 3 & 11 & 2 & 0 & 7 \\
\hline & & Hamataliwa rufocaligata Simon, 1898 & 0 & 0 & 0 & 0 & 0 & 0 & 1 & 0 \\
\hline & & Hamataliwa strandi (Lessert, 1923) & 0 & 0 & 0 & 0 & 1 & 0 & 0 & 0 \\
\hline & Oxyopes & Oxyopes bonneti Lessert, 1933 & 0 & 10 & 0 & 0 & 1 & 0 & 0 & 0 \\
\hline & & Oxyopes dumonti Vinson, 1863 & 0 & 2 & 0 & 1 & 0 & 0 & 0 & 0 \\
\hline & & Oxyopes falconeri Lessert, 1915 & 7 & 5 & 15 & 1 & 13 & 0 & 2 & 8 \\
\hline & & Oxyopes flavipalpis (Lukas, 1858) & 0 & 1 & 1 & 0 & 0 & 1 & 0 & 1 \\
\hline & & Oxyopes hoggi Lessert, 1915 & 3 & 1 & 0 & 0 & 0 & 0 & 1 & 0 \\
\hline & & Oxyopes jacksoni Lessert, 1915 & 0 & 0 & 0 & 0 & 2 & 0 & 0 & 1 \\
\hline & & Oxyopes Iongispinosus Lawrence, 1938 & 0 & 0 & 0 & 0 & 0 & 1 & 0 & 0 \\
\hline & & Oxyopes pallidecoloratus Strand, 1906 & 0 & 2 & 0 & 0 & 0 & 0 & 0 & 0 \\
\hline & & Oxyopes russoi Caporiacco, 1940 & 3 & 1 & 5 & 0 & 0 & 0 & 0 & 4 \\
\hline & & Oxyopes schenkeli Lessert, 1927 & 0 & 1 & 0 & 0 & 0 & 3 & 0 & 0 \\
\hline & & Oxyopes sp. 1 & 0 & 0 & 0 & 0 & 1 & 0 & 1 & 0 \\
\hline & & Oxyopes sp. 2 & 0 & 5 & 0 & 0 & 0 & 0 & 0 & 0 \\
\hline & & Oxyopes sp. 3 & 0 & 1 & 0 & 1 & 0 & 0 & 0 & 1 \\
\hline & & Oxyopes sp. 4 & 1 & 0 & 0 & 0 & 0 & 0 & 0 & 1 \\
\hline & Peucetia & Peucetia crucifera Lawrence, 1927 & 2 & 1 & 0 & 0 & 2 & 0 & 0 & 1 \\
\hline \multirow[t]{4}{*}{ Palpimanidae } & Diaphorocellus & Diaphorocellus biplagiatus Simon, 1893 & 0 & 0 & 3 & 0 & 0 & 0 & 0 & 0 \\
\hline & Palpimanus & Palpimanus pseudarmatus Lawrence, 1952 & 0 & 0 & 0 & 0 & 0 & 0 & 0 & 1 \\
\hline & & Palpimanus sp. 2 & 0 & 0 & 0 & 0 & 0 & 0 & 0 & 1 \\
\hline & & Palpimanus sp. 3 & 0 & 0 & 0 & 0 & 2 & 0 & 0 & 0 \\
\hline \multirow[t]{11}{*}{ Philodromidae } & & gen. n., sp. n. & 0 & 0 & 0 & 0 & 0 & 3 & 0 & 0 \\
\hline & Hirriusa & Hirriusa variegata (Simon, 1895) & 0 & 0 & 0 & 7 & 1 & 0 & 0 & 0 \\
\hline & Philodromus & Philodromus bigibbus (0.P-Cambridge, 1876) & 6 & 1 & 3 & 0 & 0 & 0 & 0 & 0 \\
\hline & & Philodromus browningi Lawrence, 1952 & 0 & 1 & 0 & 0 & 0 & 0 & 0 & 0 \\
\hline & & Philodromus guineensis Millot, 1941 & 5 & 2 & 0 & 0 & 2 & 0 & 0 & 3 \\
\hline & & Philodromus sp. 1 & 3 & 1 & 1 & 2 & 0 & 0 & 0 & 0 \\
\hline & Suemus & Suemus punctatus Lawrence, 1938 & 1 & 1 & 0 & 0 & 0 & 0 & 0 & 0 \\
\hline & Thanatus & Thanatus dorsilineatus Jézéquel, 1964 & 0 & 0 & 2 & 0 & 0 & 0 & 0 & 0 \\
\hline & Tibellus & Tibellus australis (Simon, 1910) & 0 & 6 & 0 & 0 & 0 & 0 & 3 & 0 \\
\hline & & $\begin{array}{l}\text { Tibellus cobusi Van den Berg \& Dippenaar- } \\
\text { Schoeman, } 1994\end{array}$ & 0 & 3 & 0 & 0 & 0 & 0 & 0 & 0 \\
\hline & & Tibellus minor Lessert, 1919 & 1 & 0 & 1 & 0 & 1 & 0 & 0 & 0 \\
\hline \multirow[t]{3}{*}{ Pholcidae } & Quamtana & Quamtana hectori Huber, 2003 & 0 & 0 & 1 & 7 & 0 & 0 & 0 & 0 \\
\hline & Smeringopus & Smeringopus natalensis Lawrence, 1947 & 2 & 5 & 0 & 1 & 1 & 11 & 7 & 2 \\
\hline & Spermophora & Spermophora sp. 1 & 0 & 0 & 1 & 0 & 0 & 4 & 0 & 0 \\
\hline \multirow[t]{4}{*}{ Pisauridae } & Afropisaura & Afropisaura rothiformis (Strand, 1908) & 0 & 0 & 0 & 0 & 1 & 0 & 0 & 0 \\
\hline & Euprosthenopsis & Euprosthenopsis vuattouxi Blandin, 1977 & 0 & 0 & 0 & 0 & 1 & 0 & 0 & 0 \\
\hline & Maypacius & Maypacius roeweri Blandin, 1975 & 0 & 0 & 0 & 0 & 0 & 0 & 0 & 1 \\
\hline & Thalassius & Thalassius massajae (Pavesi, 1883) & 0 & 1 & 0 & 0 & 0 & 0 & 0 & 0 \\
\hline
\end{tabular}


Appendix 1 (continued)

\begin{tabular}{|c|c|c|c|c|c|c|c|c|c|c|}
\hline \multirow[t]{2}{*}{ Family } & \multirow[t]{2}{*}{ Genus } & \multirow[t]{2}{*}{ Species } & \multicolumn{4}{|c|}{ BNR } & \multicolumn{4}{|c|}{ Little Leigh } \\
\hline & & & KA & PV & SB & SA & BA & GF & KW & PR \\
\hline \multirow[t]{5}{*}{ Prodidomidae } & Austrodomus & Austrodomus sp. 1 & 0 & 0 & 1 & 2 & 3 & 0 & 0 & 0 \\
\hline & Prodidomus & Prodidomus capensis Purcell, 1904 & 0 & 0 & 0 & 0 & 1 & 0 & 0 & 0 \\
\hline & Theuma & Theuma fusca Purcell, 1907 & 1 & 0 & 0 & 0 & 0 & 0 & 0 & 0 \\
\hline & & Theuma sp. 1 possibly new & 0 & 0 & 0 & 0 & 0 & 0 & 1 & 0 \\
\hline & & Theuma sp. 2 & 0 & 0 & 0 & 0 & 0 & 0 & 0 & 2 \\
\hline \multirow[t]{44}{*}{ Salticidae } & Asemonea & Asemonea sp. 1 possibly new & 0 & 0 & 0 & 0 & 0 & 6 & 0 & 0 \\
\hline & Bianor & Bianor sp. 1 & 0 & 0 & 1 & 0 & 1 & 0 & 0 & 0 \\
\hline & Cyrba & Cyrba lineata Wanless, 1984 & 0 & 0 & 0 & 0 & 1 & 8 & 0 & 4 \\
\hline & & Cyrba nigrimana Simon, 1900 & 0 & 2 & 1 & 0 & 0 & 0 & 0 & 1 \\
\hline & Evarcha & Evarcha cf. ignea Wesolowska \& Cumming, 2008 & 1 & 1 & 0 & 0 & 0 & 0 & 0 & 2 \\
\hline & & Evarcha prosimilis Weslowska \& Cumming, 2008 & 0 & 0 & 0 & 0 & 1 & 0 & 0 & 0 \\
\hline & & Aelurillinae possibly gen. n., sp. n & 0 & 0 & 2 & 0 & 3 & 0 & 0 & 0 \\
\hline & Heliophanus & Heliophanus proszynskii Wesolowska, 2003 & 0 & 1 & 0 & 0 & 0 & 0 & 0 & 0 \\
\hline & & Heliophanus trepidus Simon, 1910 & 0 & 5 & 0 & 0 & 0 & 0 & 0 & 1 \\
\hline & Holcolaetis & Holcolaetis zuluensis Lawrence, 1937 & 0 & 0 & 0 & 0 & 1 & 2 & 1 & 0 \\
\hline & Hyllus & Hyllus argyrotoxus Simon, 1902 & 1 & 1 & 0 & 3 & 2 & 0 & 1 & 3 \\
\hline & & Hyllus brevitarsis Simon, 1902 & 3 & 1 & 2 & 1 & 1 & 0 & 1 & 1 \\
\hline & & Hyllus dotatus (Peckham \& Peckham, 1903) & 2 & 4 & 1 & 1 & 1 & 0 & 1 & 2 \\
\hline & & Hyllus treleaveni Pekham \& Peckham, 1902 & 0 & 1 & 0 & 1 & 0 & 0 & 0 & 1 \\
\hline & Langelurillus & Langelurillus sp. 1 possibly new & 0 & 0 & 0 & 0 & 5 & 0 & 0 & 0 \\
\hline & Menemerus & Menemerus eburnensis Berland \& Millot, 1941 & 0 & 0 & 2 & 0 & 0 & 0 & 2 & 0 \\
\hline & & Menemerus fagei Berland \& Millot, 1941 & 0 & 0 & 2 & 0 & 0 & 0 & 0 & 0 \\
\hline & & Menemerus cf. minshullae Wesolowska, 1999 & 2 & 1 & 0 & 0 & 0 & 0 & 1 & 0 \\
\hline & & Menemerus zimbabwensis Wesolowska, 1999 & 0 & 0 & 1 & 1 & 0 & 0 & 2 & 0 \\
\hline & Mexcala & Mexcala sp. 1 & 0 & 1 & 0 & 0 & 0 & 0 & 0 & 0 \\
\hline & Monomotapa & Monomotapa principalis Wesolowska, 2000 & 0 & 0 & 3 & 0 & 0 & 0 & 0 & 0 \\
\hline & Myrmarachne & Myrmarachne ichneumon Simon, 1886 & 0 & 0 & 0 & 0 & 0 & 1 & 0 & 0 \\
\hline & Natta & Natta horizontalis Karsch, 1879 & 0 & 1 & 3 & 1 & 0 & 0 & 0 & 0 \\
\hline & Pachyballus & Pachyballus transversus Simon, 1900 & 0 & 0 & 0 & 0 & 0 & 1 & 0 & 0 \\
\hline & Pellenes & Pellenes pulcher Logunov, 1995 & 0 & 0 & 0 & 0 & 0 & 0 & 1 & 0 \\
\hline & & Pellenes rufoclypeatus Peckham \& Peckham, 1903 & 0 & 1 & 0 & 0 & 0 & 0 & 0 & 0 \\
\hline & Phintella & Phintella sp. 1 & 0 & 0 & 0 & 0 & 0 & 3 & 0 & 0 \\
\hline & Phlegra & Phlegra cf. procera Wesolowska \& Cumming, 2008 & 0 & 1 & 1 & 0 & 1 & 0 & 0 & 0 \\
\hline & & Phlegra cf. varia Wesolowska \& Russell-Smith, 2000 & 0 & 0 & 1 & 0 & 1 & 0 & 0 & 0 \\
\hline & & Phlegra sp. 1 & 0 & 0 & 0 & 1 & 0 & 0 & 0 & 0 \\
\hline & Pignus & Pignus simoni (Peckham \& Peckham 1903) & 0 & 2 & 2 & 1 & 0 & 0 & 1 & 1 \\
\hline & Pseudicius & Pseudicius (nuclearis-group) sp. 1 possibly new & 0 & 0 & 0 & 1 & 2 & 0 & 2 & 1 \\
\hline & Rhene & Rhene sp. 1 & 0 & 0 & 0 & 0 & 1 & 0 & 0 & 0 \\
\hline & Stenaelurillus & Stenaelurillus natalensis Haddad \& Wesolowska, 2006 & 24 & 15 & 6 & 13 & 1 & 1 & 0 & 16 \\
\hline & Thyene & Thyene inflata (Gerstaecker, 1873) & 1 & 0 & 0 & 0 & 3 & 0 & 2 & 2 \\
\hline & & Thyene natalii Peckham \& Peckham, 1903 & 1 & 1 & 0 & 0 & 2 & 1 & 3 & 0 \\
\hline & & Thyene ogdeni leighi (Peckham \& Peckham, 1903) & 0 & 0 & 0 & 0 & 0 & 0 & 0 & 1 \\
\hline & & Thyene ogdeni Peckham \& Peckham, 1903 & 0 & 1 & 0 & 0 & 2 & 0 & 0 & 1 \\
\hline & & Thyene semiargentea (Simon, 1884) & 2 & 2 & 0 & 1 & 1 & 0 & 0 & 2 \\
\hline & & Thyene thyenioides (Lessert, 1925) & 0 & 1 & 1 & 0 & 2 & 0 & 0 & 2 \\
\hline & Thyenula & Thyenula oranjensis Wesolowska, 2001 & 0 & 0 & 0 & 0 & 0 & 5 & 0 & 0 \\
\hline & & Thyenula sempiterna Wesolowska, 2000 & 0 & 0 & 0 & 0 & 0 & 16 & 0 & 0 \\
\hline & Tomocyrba & Tomocyrba sp. 1 & 0 & 1 & 0 & 0 & 0 & 3 & 0 & 0 \\
\hline & Tusitala & Tusitala barbata Peckham \& Peckham, 1902 & 0 & 1 & 0 & 3 & 0 & 0 & 0 & 1 \\
\hline
\end{tabular}


Appendix 1 (continued)

\begin{tabular}{|c|c|c|c|c|c|c|c|c|c|c|}
\hline \multirow[t]{2}{*}{ Family } & \multirow[t]{2}{*}{ Genus } & \multirow[t]{2}{*}{ Species } & \multicolumn{4}{|c|}{ BNR } & \multicolumn{4}{|c|}{ Little Leigh } \\
\hline & & & KA & PV & SB & SA & $\mathrm{BA}$ & GF & KW & PR \\
\hline \multirow[t]{3}{*}{ Scytodidae } & Scytodes & Scytodes maritima Lawrence, 1938 & 2 & 1 & 0 & 0 & 0 & 1 & 0 & 2 \\
\hline & & Scytodes cf. quinqua Lawrence, 1927 & 0 & 0 & 0 & 0 & 0 & 1 & 0 & 0 \\
\hline & & Scytodes sp. 1 & 0 & 1 & 0 & 0 & 0 & 2 & 1 & 2 \\
\hline \multirow[t]{3}{*}{ Selenopidae } & Anyphops & Anyphops sp. 1 & 0 & 0 & 0 & 0 & 0 & 2 & 0 & 0 \\
\hline & & Anyphops barbertonensis (Lawrence, 1940) & 0 & 0 & 0 & 0 & 0 & 1 & 0 & 0 \\
\hline & Selenops & Selenops brachycephalus Lawrence, 1940 & 0 & 0 & 0 & 0 & 0 & 0 & 1 & 0 \\
\hline \multirow[t]{2}{*}{ Sicariidae } & Loxosceles & Loxosceles spiniceps Lawrence, 1952 & 0 & 4 & 0 & 3 & 0 & 0 & 0 & 0 \\
\hline & Sicarius & Sicarius oweni (Newlands, unpubl.) & 0 & 0 & 0 & 0 & 0 & 0 & 1 & 0 \\
\hline \multirow[t]{5}{*}{ Sparassidae } & Eusparassus & Eusparassus palystiformis Strand, 1907 & 0 & 0 & 0 & 0 & 0 & 0 & 2 & 0 \\
\hline & Olios & Olios correvoni Lessert, 1921 & 1 & 0 & 0 & 1 & 0 & 0 & 0 & 4 \\
\hline & & Olios freyi Lessert, 1929 & 0 & 1 & 0 & 0 & 0 & 0 & 0 & 0 \\
\hline & & Olios sp. 3 & 1 & 0 & 0 & 0 & 0 & 0 & 0 & 0 \\
\hline & Pseudomicrommata & $\begin{array}{l}\text { Pseudomicrommata longipes (Bösenberg \& } \\
\text { Lenz, 1895) }\end{array}$ & 2 & 0 & 0 & 0 & 0 & 0 & 0 & 0 \\
\hline \multirow[t]{3}{*}{ Tetragnathidae } & Leucauge & Leucauge levanderi (Kulczynski, 1901) & 0 & 0 & 0 & 0 & 0 & 4 & 0 & 0 \\
\hline & Meta & Meta sp. 1 & 0 & 0 & 0 & 0 & 0 & 2 & 0 & 0 \\
\hline & Tetragnatha & Tetragnatha boydi O.P.-Cambridge, 1898 & 0 & 0 & 0 & 0 & 0 & 1 & 0 & 0 \\
\hline Theraphosidae & Ceratogyrus & Ceratogyrus darlingi Pocock, 1897 & 0 & 0 & 0 & 0 & 0 & 0 & 0 & 1 \\
\hline \multirow[t]{24}{*}{ Theridiidae } & Anelosimus & Anelosimus sp. 1 & 0 & 0 & 2 & 2 & 2 & 0 & 3 & 2 \\
\hline & Archaearanea & Archaearanea sp. 1 & 0 & 0 & 0 & 0 & 0 & 1 & 0 & 0 \\
\hline & Argyrodes & Argyrodes zonatus (Walckenaer, 1842) & 0 & 0 & 0 & 0 & 0 & 2 & 0 & 2 \\
\hline & Chorizopella & Chorizopella tragardhi Lawrence, 1947 & 0 & 0 & 0 & 0 & 0 & 1 & 1 & 0 \\
\hline & Coleosoma & Coleosoma sp. 1 & 0 & 0 & 0 & 0 & 0 & 0 & 0 & 1 \\
\hline & Coscinides & Coscinides sp. 1 & 1 & 0 & 0 & 0 & 0 & 0 & 0 & 2 \\
\hline & Episinus & Episinus bilineatus Simon, 1894 & 0 & 0 & 0 & 0 & 0 & 0 & 0 & 1 \\
\hline & & Episinus sp. 1 & 0 & 1 & 0 & 0 & 1 & 1 & 2 & 0 \\
\hline & Euryopis & Euryopis funebris (Hentz, 1850) & 0 & 2 & 0 & 0 & 1 & 0 & 1 & 1 \\
\hline & & Euryopis sp. 2 & 0 & 0 & 2 & 3 & 0 & 0 & 0 & 2 \\
\hline & Latrodectus & Latrodectus geometricus C.L. Koch, 1841 & 1 & 0 & 1 & 0 & 1 & 0 & 0 & 0 \\
\hline & & Latrodectus renivulvatus Dahl, 1902 & 0 & 0 & 1 & 0 & 0 & 0 & 0 & 0 \\
\hline & Phoroncidia & Phoroncidia eburnea (Simon, 1885) & 0 & 0 & 0 & 0 & 20 & 0 & 0 & 1 \\
\hline & & Phoroncidia sp. 1 & 0 & 0 & 0 & 0 & 12 & 1 & 0 & 0 \\
\hline & Steatoda & Steatoda sp. 1 & 0 & 0 & 0 & 0 & 0 & 2 & 0 & 0 \\
\hline & Theridion & Theridion sp. 1 & 1 & 2 & 2 & 2 & 9 & 2 & 0 & 3 \\
\hline & & Theridion sp. 2 & 1 & 1 & 0 & 0 & 0 & 4 & 2 & 0 \\
\hline & & Theridion sp. 3 & 0 & 0 & 0 & 0 & 2 & 1 & 1 & 0 \\
\hline & & Theridion sp. 4 & 1 & 1 & 0 & 0 & 1 & 0 & 2 & 0 \\
\hline & Thymoites & Thymoites sp. 1 & 0 & 0 & 0 & 0 & 0 & 2 & 1 & 0 \\
\hline & & Theridiidae sp. 1 & 0 & 0 & 0 & 0 & 0 & 6 & 1 & 1 \\
\hline & & Theridiidae sp. 2 & 0 & 0 & 0 & 0 & 0 & 0 & 4 & 0 \\
\hline & & Theridiidae sp. 3 & 0 & 0 & 0 & 0 & 1 & 0 & 0 & 0 \\
\hline & & Theridiidae sp. 4 & 0 & 0 & 0 & 0 & 1 & 0 & 0 & 0 \\
\hline \multirow[t]{7}{*}{ Thomisidae } & Heriaesynema & Heriaesynema sp. 1 possibly new & 0 & 0 & 0 & 0 & 1 & 0 & 0 & 0 \\
\hline & Heriaeus & Heriaeus sp. 1 & 0 & 0 & 0 & 2 & 0 & 0 & 0 & 0 \\
\hline & & Heriaeus transvaalicus Simon, 1985 & 5 & 2 & 0 & 0 & 0 & 0 & 0 & 0 \\
\hline & Misumenops & Misumenops rubrodecoratus Millot, 1941 & 0 & 0 & 3 & 8 & 0 & 0 & 0 & 1 \\
\hline & Monaeses & Monaeses austrinus Simon, 1910 & 0 & 0 & 0 & 0 & 0 & 0 & 2 & 2 \\
\hline & Oxytate & Oxytate argenteooculata (Strand, 1886) & 0 & 0 & 0 & 0 & 1 & 3 & 0 & 0 \\
\hline & Ozyptila & Ozyptila sp. 1 & 0 & 0 & 0 & 0 & 0 & 0 & 0 & 1 \\
\hline
\end{tabular}


Appendix 1 (continued)

\begin{tabular}{|c|c|c|c|c|c|c|c|c|c|c|}
\hline \multirow[t]{2}{*}{ Family } & \multirow[t]{2}{*}{ Genus } & \multirow[t]{2}{*}{ Species } & \multicolumn{4}{|c|}{ BNR } & \multicolumn{4}{|c|}{ Little Leigh } \\
\hline & & & KA & PV & SB & SA & $\mathrm{BA}$ & GF & KW & $\mathrm{PR}$ \\
\hline & Paramystaria & Paramystaria variabilis Lessert, 1919 & 4 & 0 & 7 & 8 & 1 & 2 & 3 & 1 \\
\hline & Parasmodix & Parasmodix quadrituberculata Jézéquel, 1966 & 0 & 0 & 1 & 2 & 0 & 0 & 0 & 0 \\
\hline & Pherecydes & $\begin{array}{l}\text { Pherecydes ionae Dippenaar-Schoeman, } 1980 \\
\text { Pherecydes lucinae Dippenaar-Schoeman, } 1980\end{array}$ & $\begin{array}{l}0 \\
1\end{array}$ & $\begin{array}{l}0 \\
0\end{array}$ & $\begin{array}{l}0 \\
0\end{array}$ & $\begin{array}{l}0 \\
0\end{array}$ & $\begin{array}{l}0 \\
0\end{array}$ & $\begin{array}{l}4 \\
0\end{array}$ & $\begin{array}{l}0 \\
0\end{array}$ & $\begin{array}{l}0 \\
0\end{array}$ \\
\hline & Runcinia & Runcinia flavida Simon, 1881 & 15 & 18 & 21 & 3 & 9 & 0 & 10 & 10 \\
\hline & Simorcus & Simorcus cotti Lessert, 1936 & 0 & 4 & 1 & 2 & 3 & 0 & 0 & 3 \\
\hline & Smodicinus & Smodicinus coroniger Simon, 1895 & 5 & 0 & 0 & 0 & 0 & 0 & 0 & 0 \\
\hline & Stiphropus & Stiphropus bisigillatus Lawrence, 1952 & 0 & 3 & 0 & 0 & 0 & 0 & 0 & 0 \\
\hline & Synema & Synema imitator (Pavesi, 1883) & 0 & 0 & 0 & 0 & 0 & 1 & 2 & 0 \\
\hline & Thomisops & Thomisops pupa Karsch, 1879 & 1 & 0 & 1 & 0 & 0 & 0 & 1 & 0 \\
\hline & Thomisus & $\begin{array}{l}\text { Thomisus citrinellus Simon, } 1875 \\
\text { Thomisus congoensis Comellini, } 1957 \\
\text { Thomisus daradioides Simon, } 1890 \\
\text { Thomisus granulatus Karsch, } 1880 \\
\text { Thomisus kalaharinus Lawrence, } 1936 \\
\text { Thomisus scrupeus (Simon, 1886) }\end{array}$ & $\begin{array}{l}0 \\
0 \\
0 \\
0 \\
0 \\
1\end{array}$ & $\begin{array}{l}0 \\
1 \\
1 \\
1 \\
0 \\
1\end{array}$ & $\begin{array}{r}0 \\
0 \\
3 \\
0 \\
1 \\
10\end{array}$ & $\begin{array}{l}0 \\
0 \\
0 \\
0 \\
0 \\
0\end{array}$ & $\begin{array}{l}0 \\
0 \\
0 \\
0 \\
0 \\
0\end{array}$ & $\begin{array}{l}0 \\
0 \\
0 \\
0 \\
0 \\
2\end{array}$ & $\begin{array}{l}0 \\
1 \\
1 \\
0 \\
0 \\
0\end{array}$ & $\begin{array}{l}1 \\
0 \\
3 \\
0 \\
0 \\
1\end{array}$ \\
\hline & Tmarus & $\begin{array}{l}\text { Tmarus africanus Lessert, } 1919 \\
\text { Tmarus cameliformis Millot, } 1942 \\
\text { Tmarus comellinii Garcia-Neto, } 1989 \\
\text { Tmarus planetarius Simon, } 1903\end{array}$ & $\begin{array}{l}4 \\
3 \\
0 \\
0\end{array}$ & $\begin{array}{l}0 \\
4 \\
0 \\
2\end{array}$ & $\begin{array}{l}6 \\
9 \\
0 \\
0\end{array}$ & $\begin{array}{l}0 \\
3 \\
0 \\
0\end{array}$ & $\begin{array}{l}4 \\
0 \\
0 \\
0\end{array}$ & $\begin{array}{l}0 \\
0 \\
0 \\
0\end{array}$ & $\begin{array}{l}2 \\
4 \\
1 \\
0\end{array}$ & $\begin{array}{l}7 \\
3 \\
0 \\
0\end{array}$ \\
\hline Trochanteriidae & Platyoides & Platyoides walteri (Karsch, 1886) & 0 & 0 & 0 & 0 & 1 & 0 & 0 & 0 \\
\hline \multirow[t]{3}{*}{ Uloboridae } & Hyptiotes & Hyptiotes ackermani Wiehle, 1964 & 0 & 0 & 0 & 0 & 0 & 1 & 0 & 0 \\
\hline & Miagrammopes & Miagrammopes brevicaudus 0.P.-Cambridge, 1882 & 0 & 0 & 0 & 0 & 0 & 1 & 0 & 0 \\
\hline & Uloborus & Uloborus sp. 1 & 0 & 0 & 0 & 0 & 0 & 1 & 0 & 0 \\
\hline \multirow[t]{5}{*}{ Zodariidae } & Capheris & $\begin{array}{l}\text { Capheris crassimana (Simon, 1887) } \\
\text { Capheris decorata Simon, } 1904\end{array}$ & $\begin{array}{l}0 \\
0\end{array}$ & $\begin{array}{l}1 \\
0\end{array}$ & $\begin{array}{l}0 \\
1\end{array}$ & $\begin{array}{r}0 \\
10\end{array}$ & $\begin{array}{l}0 \\
1\end{array}$ & $\begin{array}{l}0 \\
0\end{array}$ & $\begin{array}{l}0 \\
0\end{array}$ & $\begin{array}{l}0 \\
1\end{array}$ \\
\hline & Chariobas & Chariobas cylindriceus Simon, 1893 & 0 & 0 & 0 & 0 & 1 & 0 & 0 & 1 \\
\hline & Cydrela & $\begin{array}{l}\text { Cydrela schoemanae Jocqué, } 1991 \\
\text { Cydrela sp. } 1\end{array}$ & $\begin{array}{l}0 \\
0\end{array}$ & $\begin{array}{r}0 \\
16\end{array}$ & $\begin{array}{l}0 \\
6\end{array}$ & $\begin{array}{r}0 \\
13\end{array}$ & $\begin{array}{l}0 \\
0\end{array}$ & $\begin{array}{l}1 \\
3\end{array}$ & $\begin{array}{l}0 \\
0\end{array}$ & $\begin{array}{l}0 \\
0\end{array}$ \\
\hline & Diores & $\begin{array}{l}\text { Diores sp. } 1 \\
\text { Diores sp. } 2\end{array}$ & $\begin{array}{l}0 \\
0\end{array}$ & $\begin{array}{l}7 \\
1\end{array}$ & $\begin{array}{l}4 \\
0\end{array}$ & $\begin{array}{l}2 \\
0\end{array}$ & $\begin{array}{l}0 \\
0\end{array}$ & $\begin{array}{l}0 \\
1\end{array}$ & $\begin{array}{l}0 \\
2\end{array}$ & $\begin{array}{l}5 \\
0\end{array}$ \\
\hline & Ranops & Ranops sp. 1 possibly new & 0 & 0 & 0 & 2 & 0 & 5 & 0 & 0 \\
\hline
\end{tabular}

